\title{
Farm succession and retirement: Some international comparisons
}

\author{
Matt Lobley ${ }^{a}$ \\ University of Exeter, Department of Politics \\ John R. Bakerb \\ Iowa State University, Beginning Farmer Center \\ Ian Whiteheadc \\ University of Plymouth, School of Geography, Earth and Environmental Sciences
}

Submitted 2 March 2010 / Accepted 22 June 2010/ Published online August 2010

Copyright (C) 2010 by New Leaf Associates, Inc.

\begin{abstract}
The increasing age of farmers and the reluctance to transfer management from the owning generation to the successor generation has been well documented by several studies. In this article we review the literature relating to the succession of farm businesses. Drawing on data from the international FARMTRANSFERS project, we explore attitudes toward retirement and also rates and patterns of succession in several contrasting countries and states in the United States. Lastly, we
\end{abstract}

\footnotetext{
${ }^{a}$ Centre for Rural Policy Research, Department of Politics, University of Exeter, Amory Building, Rennes Drive, Exeter, UK. EX4 4RJ; m.lobley@exeter.ac.uk; +44 (0)1392 264539 (corresponding author)

b Beginning Farmer Center, Iowa State University, 10861 Douglas Avenue, Suite B, Urbandale, Iowa, 50167; jrbaker@iastate.edu; 515-677-2445

c School of Geography, Earth and Environmental Sciences, University of Plymouth, Drake Circus, Plymouth, UK. PL4 8AA: iwhitehead@plymouth.ac uk; +44 (0)1752 585913
}

discuss the implications of the research and provide recommendations for public policies that would enhance the opportunities for successors to succeed in the continuation of the farm family business.

\section{Key Words}

Farm transfers, intergenerational succession, retirement; retirement age, successor effect, succession ladder

\section{Introduction and Literature Review}

As with many family businesses, often one of the prime objectives of farm families is to pass on control of a sound and improved business to the next generation (Gasson and Errington, 1993). Despite declining numbers of farms in many parts of the western world, coupled with the expansion of corporate farming, family farming remains of totemic importance. Intergenerational succession represents the renewal of the family farm and can potentially act as a helpful corrective in addressing the apparent increasingly aged population of 
principal farmers. In contrast to many other professions in contemporary society, farming remains a largely inherited occupation and one in which the transfer of business control and ownership to the next generation is arguably one of the most critical stages in the development of the business (Uchiyama, Lobley, Errington, and Yanagimura, 2008). Moreover, evidence suggests that rates of intergenerational succession are much higher in farming than in other self-employed occupations (Laband and Lentz, 1983). And, in the case of the family farm, intergenerational succession tends to also be intrafamilial succession.

For instance, in the United Kingdom families are responsible for most farms and much of the farmed land. A survey of 255 farmers in six areas of England found that 84 percent operated "established family farms" (that is, farms run by operators who are at least the second generation of their family to be farming the same farm or nearby farm), and were responsible for managing 86 percent of the area covered by the survey (Lobley, Errington, McGeorge, Millard, and Potter, 2002). Sometimes, family occupancy of the farm or local farmland was extremely lengthy: 31 percent of established family farmers could trace their family's occupancy of the farm to 1900 or earlier. The main entry route into farming in England remains intergenerational transfer within a family (ADAS, 2004; Lobley, et al., 2002). Similarly, in Australia, despite falling rates of succession, some 94 percent of farms are family-owned and -operated. Many farmers can trace their family's occupation of the farm back three generations or more, and there is evidence of a strong "rural ideology" that prioritizes passing on the farm within the family (Barclay, Foskey, and Reeve, 2005).

Patterns of ownership in the United States are similar to those found in the UK and Australia. In the U.S. over 98 percent of all farms are family farms, and those farm families own 93.5 percent of all farmland (Hoppe and Banker, 2006). In Iowa, the average length of ownership of family farms was 83 years (Korsching, Lasley, and Gruber, 2007). Farmers in the eastern United States may, in some cases, trace their ownership to the early 17 th century; an example is the Shirley Plantation in Virginia, which was established in 1613 (Clay, 2006). In the western United States, farm family ownership of land may be more recent in origin. Indeed, the last homestead land patent was granted in Alaska in 1988 (National Park Service, 2007).

The intergenerational and intrafamilial transfer of farms can be a source of great strength. In most cases the successor is a child of the manager, and in addition to physical assets, intangible assets (e.g., tacit knowledge) are transferred to the new business principal (Uchiyama, et al., 2008). The highly detailed and locally specific knowledge associated with successful intergenerational transfers can prove vital for effective agricultural and environmental management and can engender a sense of intergenerational accountability (Burton, Mansfield, Schwarz, Brown, and Convery, 2005). The source of such strength can also be a source of problems, however, not least of which is the potential for conflict between the generations, avoidance of discussing the issues (Barclay, et al., 2005; Symes, 1990) and sometimes the treatment of a successor as a "farmer's boy" (Gasson and Errington,1993). In the latter case, a successor is essentially treated as a hired worker, given little opportunity to develop the managerial skills needed to operate the family business, and kept in place by the promise that the eventual reward will be ownership of the family farm (Lobley, 2010).

Succession is not a single event but is (or should be) a process that takes place over an extended period of time. Succession is the process of transferring the management of business assets. This may involve the transfer of the management of the "home farm" to a successor (or multiple successors), or it may involve the transfer of the necessary capital to establish a new farm business. Accordingly, it is possible to distinguish between succession to the farm and succession to the occupation of farming. In addition to succeeding to the farm and/or the occupation, the successor also benefits from the transfer of skills and, frequently, less tangible assets such as a detailed knowledge of the home farm, its microclimate and its idiosyncrasies (Errington and Lobley, 2002). 
The mirror image of succession is retirement. Just as succession is a process rather than a single event, retirement from farming is not a single act or event but a series of transitions (Rosenblatt and Anderson, 1981). The self-employed generally face a greater range of opportunities in terms of the balance between their time devoted to work and time devoted to other activities and in the case of farming, in particular, the term "retirement" can cover a wide range of situations. At one extreme, it can refer to the process of selling and leaving farming altogether. Frequently however, it may involve withdrawal from some of the more arduous tasks alongside a continuing day-to-day involvement in the business. For some, full retirement is achieved by selling, moving away from the farm, and no longer relying on a farm to produce retirement income. For others, a pathway of semiretirement with retirement income that is to some extent dependent on farm income may, after a series of transitions, eventually lead to full retirement and a move out of the farmhouse or even off the farm entirely. Finally, inheritance denotes the legal transfer of ownership of business assets. ${ }^{1}$ Whilst conceptually separate, these processes are obviously linked, the timing and degree of ease of the process can have considerable implications for the farm business as well as the individuals involved in that business.

The twin processes of succession and retirement can be a time of considerable financial and emotional stress on farm households (Burton and Walford, 2005). In addition, evidence from the U.S. and Europe suggests that farm business performance and farm development can be influenced by succession issues (e.g. Calus, Huylenbroeck, and Lierde, 2008; Mishra and El-Osta, 2008; Potter and Lobley, 1992; Boehlje and Eidman, 1984; Harl, 1972). Such influences can operate in a number of ways. For instance the "succession effect" (Potter and Lobley, 1996) refers to the impact of the expectation of succession on the farm business. Evidence suggests that farms may be developed over a long period, in order to provide a business capable of supporting two generations or to yield

1 This does not include inter vivos gifting and purchase. sufficient capital to establish successors on separate holdings. For instance, Calus, et al. (2008) found that the value of total farm assets was significantly higher on Belgian farms where a successor was present. Similarly, using data from the 2001 Agricultural Resource Management Survey, Mishra and El-Osta (2008) identified a positive association between farm capital stock and succession decisions on U.S. farms. ${ }^{2}$ The succession effect can be reinforced by the "successor effect" (Potter and Lobley, 1996), that is, the impact of the successors themselves, as they gradually (or sometimes rapidly) assume managerial control. Successors often return from a period of agricultural training with new ideas and an innovative approach to the business. The extent of their impact will be influenced by how rapidly they ascend the "succession ladder" (Errington and Lobley, 2002).

Finally, the "retirement effect" (Potter and Lobley 1996) can be identified toward the end of a farmer's career and is most pronounced where succession has been ruled out. In these cases farm operators frequently disengage or even withdraw from agriculture, by downsizing to reduce workload, letting or selling land, and frequently farming their remaining land less intensively. In some instances, these farmers can be regarded as "capital consumers" (Lobley and Potter, 2004), progressively liquidating farm assets to provide an income as part of a gradual process of leaving farming. For example, evidence from Belgium indicates that older farmers without successors begin to disinvest and that total asset values can decline toward liquidation levels (Calus, et al., 2008). In Ireland, Symes found that farms lacking a successor were less likely to be managed intensively, and that "the production cycle declines closer to a subsistence mode in old age than at any other point in the life cycle" (Symes, 1973, p. 101).

\footnotetext{
2 In both these cases (Calus, et al., 2008; Mishra and El-Osta, 2008), statistical associations raise questions regarding causality. Do farms grow because they have a successor, or do larger farms attract a successor more easily? The concept of the succession effect would suggest the former, with growth and investment then reinforced by the successor effect.
} 
Given that farm succession and farm business development influence each other, the process of succession has implications for the social and economic sustainability of the family farm and the economy and community in which it operates. Clearly succession is, or should be, of importance to policymakers, given the evidence that the process has a considerable influence on farmer behavior. In addition, since facilitating the timely transfer of farm businesses is an explicit objective of many policy initiatives, it is important that policymakers understand the processes of intergenerational transfer. For farm advisers, a fuller understanding of the process of succession is important because at the very time when members of the new generation are seeking to improve productivity or business viability through investment, members of the older generation may be engaged in disinvestment to provide for their retirement. This is particularly likely where no separate pension provision has been made and the farm business itself is expected to provide retirement funds. Thus, advisers need to consider how to maintain a viable business for the next generation, whilst minimizing the financial and emotional stress increasingly associated with the pursuit of this goal. Against this background, this paper compares rates and patterns of succession in the U.S. (in the states of Iowa, Virginia, North Carolina, Pennsylvania and New Jersey), Canada, England and Australia. It identifies and compares plans for retirement and the financing of retirement in these countries. It also explores similarities and differences in routes to succession before going on to consider some implications for policy.

\section{Applied Research Methods}

This paper draws on both published and unpublished data from the FARMTRANSFERS project, a series of international comparative studies replicating an original survey by Errington and Tranter (1991). This international collaboration was initiated by the late Professor Andrew Errington of The University of Plymouth and John R. Baker of the Beginning Farmer Center, Iowa State University.
The project is based on a survey questionnaire originally developed by Professor Errington and subsequently replicated in a number of different countries (see table 1) to provide a standard set of data to be added to the FARMTRANSFERS database. FARMTRANSFERS is currently directed by John Baker, Matt Lobley (University of Exeter, UK) and Ian Whitehead (University of Plymouth, UK). To date over 15,600 farmers have completed the copyrighted FARMTRANSFERS questionnaire. The details of the survey in several countries have been noted in other papers (such as Uchiyama, et al., 2008; Barclay, et al., 2005; Errington, 1998; Errington and Lobley, 2002; Baker, Duffy, and Lamberti, 2001). Data is collected through a postal questionnaire covering basic background information about the farm (e.g., size, tenure, and enterprise structure) and farm family demographics (e.g., age and household composition). Detailed information is also recorded regarding retirement and succession plans, sources of advice and information, and the delegation of decisionmaking responsibility between the principal farmer and his or her successor(s). Given the wide range of social, cultural, and economic differences in the different countries and U.S. states participating in FARMTRANSFERS, modifications are made to the questionnaire to reflect such differences, with the agreement of the project directors. The questionnaires administered by country are referred to as "replications."

It should be noted that the year of the survey and sample size for each country reported here is: Iowa, 2006 (972); Pennsylvania and New Jersey, 2005 (1,271); North Carolina, 2005 (2,095), Australia, 2004 (790); England, 1997 (491); Ontario and Quebec, $1997(1,277)$. (See table 1 for a list of all FARMTRANSFERS surveys between 1991 and 2010.) The individual replications of the survey reported here span close to a decade and the sample sizes vary considerably. However, these specific replications have been selected for analysis in order to illustrate the diverse range of socioeconomic and cultural contexts in which the survey has been conducted. Clearly, the FARMTRANSFERS methodology is not without its limitations, including the variation in survey year 
and the limitations of the standardized postal questionnaire format. Nevertheless, this approach yields a range of quantitative data relating to the pattern, process, and speed of succession and retirement, which provide a firm base for future indepth inquiries. Moreover, it allows for an international comparison of the results, which is not possible using other data sets. As such, the data is invaluable in order to identify common elements of succession plans, determine educational needs of farm business owners, compare succession patterns internationally, and create a resource useful to farm business operators for future succession activities.

Table 1. FARMTRANSFERS Surveys Conducted 1991-2010

\begin{tabular}{|c|c|c|}
\hline $\begin{array}{l}1991 \text { England } \\
1993 \text { France }\end{array}$ & $\begin{array}{c}2003 \text { Germany } \\
2003 \text { Poland }\end{array}$ & $\begin{array}{c}2005 \\
\text { Pennsylvania \& } \\
\text { New Jersey }\end{array}$ \\
\hline $\begin{array}{l}1997 \text { Canada } \\
\text { (Ontario \& } \\
\text { Quebec) }\end{array}$ & $\begin{array}{c}2003 \\
\text { Switzerland }\end{array}$ & $\begin{array}{l}2005 \text { North } \\
\text { Carolina }\end{array}$ \\
\hline 1997 Fnoland & 2003 Austria & 2006 lowa \\
\hline 2000 lowa & $\begin{array}{c}2004 \text { California } \\
\text { (Humboldt } \\
\text { County) }\end{array}$ & $\begin{array}{l}2006 \text { Wisconsin } \\
2009 \text { Romania }\end{array}$ \\
\hline 2001 Virginia & 2004 Australia & $\begin{array}{c}2010 \\
\text { Tennessee }\end{array}$ \\
\hline
\end{tabular}

\section{Results}

\section{Rates of Succession}

In terms of the rate of succession (i.e., the proportion of farmers with an identified successor), figure 1 provides some international comparisons and illustrates some notable differences. For instance, England has a higher rate of succession selection compared with Canada, Australia, and several U.S. states. Indeed, Iowa, Virginia, Pennsylvania, New Jersey, and North Carolina all have much lower rates of succession. In addition, figure 1 shows that the number of daughter or daughter-in-law successors internationally is low. The identification of a successor depends, at least in part, on the age of the principal farmer. On average, respondents to the survey in England were older than their
Canadian counterparts, which might explain some of the difference in rates of succession. However, farmers in the U.S. replications are noticeably older on average and yet have much lower rates of succession selection (see figure 1).

Figure 2 explores in greater detail the association between the age of the principal farmer and the likelihood of having secured a successor. Generally, the younger the farmer, the lower the rate of expected succession, with Australia being an exception to this pattern. Data from England and Canada show that the expectation of succession increases noticeably with age. On average, succession rates in Iowa, Virginia, and North Carolina remain fairly low.

\section{Delegation of Managerial Responsibilities}

As previously discussed, a major objective of the international FARMTRANSFERS project is to examine the process of succession or the process of transferring managerial control and other intangible assets, such as site- or farm-specific knowledge. In order to do this, respondents are asked to indicate if a number of specific decisions are made by the principal farmer alone, shared with the successor, or made by the successor alone. The tasks presented to the respondents represent technical, tactical, strategic planning, managerial, and financial aspects of the farm operation. Table 2 compares the international data on task delegation where each decision was assigned a score ranging from 1 (farmers themselves are solely responsible) to 5 (successors are solely responsible). A score ranging from 2 to 4 represents shared responsibility between the farmer and successor.

The results show that financial decisions are most likely to be made by the principal farmer without any help from the successor. The data also show that if successors are going to be solely responsible for a decision, that decision would most likely involve livestock management, and the selection, recruitment, and supervision of employees. With one or two exceptions, the types of decisions most frequently delegated to the successors and those not delegated to the successor are similar across international lines. 


\section{Figure 1. Identification of a successor: some international comparisons}

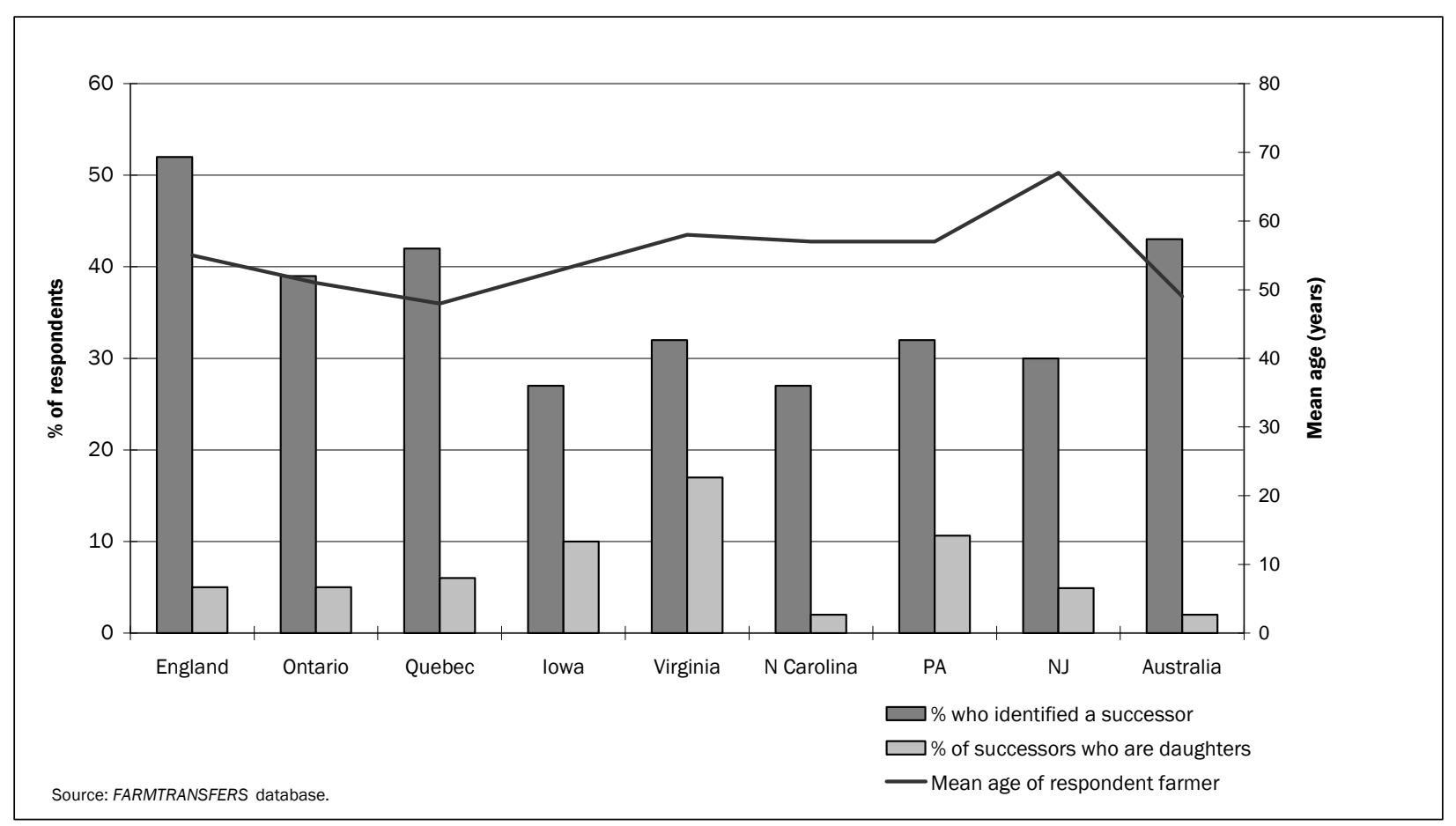

Figure 2. The association between identification of a successor and age of principal farmer (percentage of farmers responding that they have identified a successor, by age group )

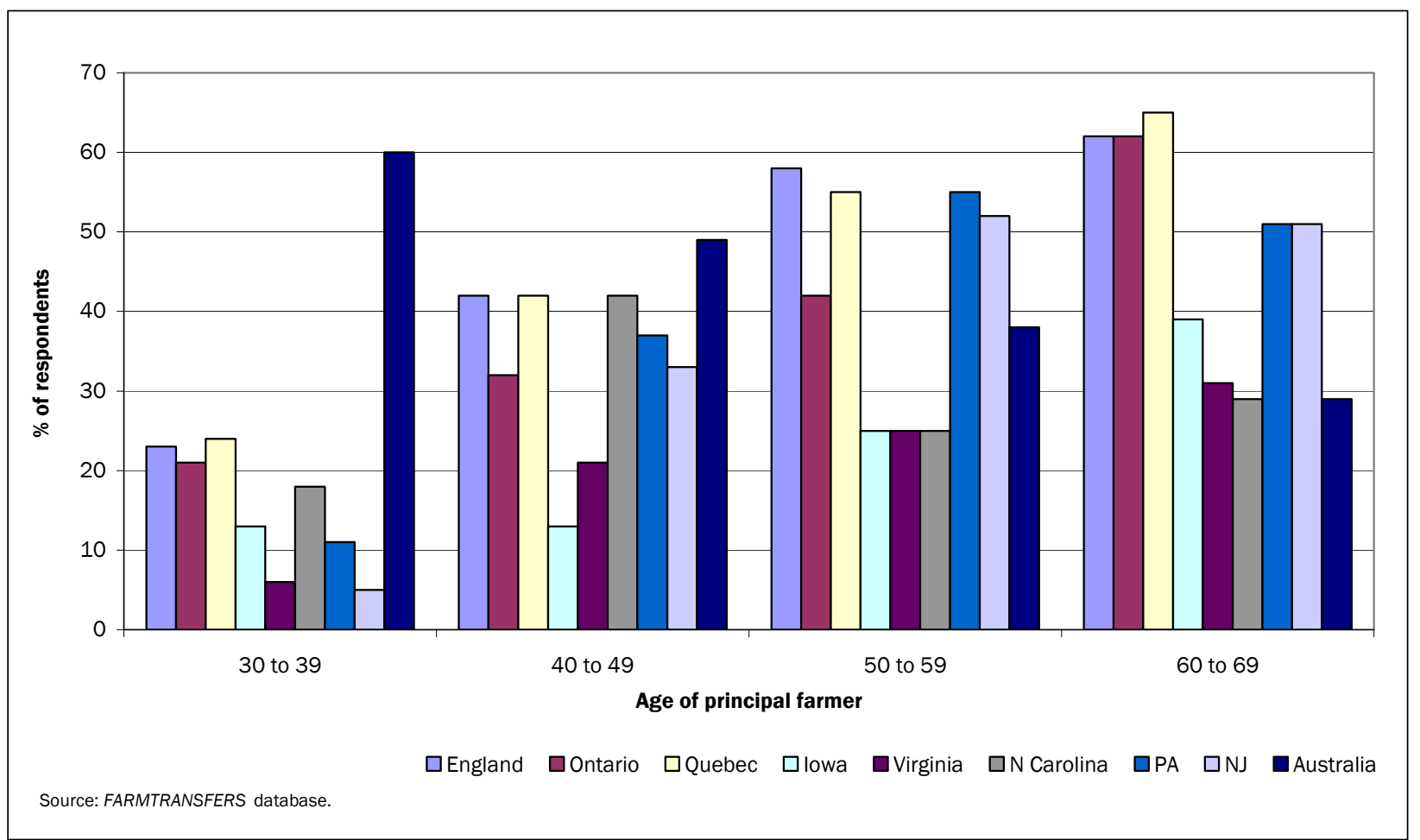


Table 2. International Comparison of Task Delegation Score

\begin{tabular}{|c|c|c|c|c|c|c|c|c|c|}
\hline Activity or Decision & $\begin{array}{l}\text { England } \\
1997\end{array}$ & $\begin{array}{c}\text { Ontario } \\
1997\end{array}$ & $\begin{array}{l}\text { Quebec } \\
1997\end{array}$ & $\begin{array}{l}\text { lowa } \\
2006\end{array}$ & $\begin{array}{l}\text { Virginia } \\
2001\end{array}$ & $\begin{array}{l}\text { NC* } \\
2005\end{array}$ & $\begin{array}{l}\mathrm{PA}^{*} \\
2005\end{array}$ & $\begin{array}{c}N J * \\
2005\end{array}$ & $\begin{array}{c}\text { Australia } \\
2004\end{array}$ \\
\hline Decides when to pay bills & 1 & 1 & 1 & 2 & 1 & 1 & 1 & 1 & 1 \\
\hline $\begin{array}{l}\text { Identifies sources and } \\
\text { negotiates loans and finance }\end{array}$ & 2 & 2 & 2 & 1 & 2 & 2 & 2 & 2 & 2 \\
\hline $\begin{array}{l}\text { Decides long-term balance and } \\
\text { type of enterprises }\end{array}$ & 6 & 7 & 10 & 12 & 5 & 7 & 12 & 13 & 3 \\
\hline $\begin{array}{l}\text { Decides and plans capital } \\
\text { projects }\end{array}$ & 5 & 5 & 8 & 3 & 7 & 4 & 7 & 8 & 4 \\
\hline $\begin{array}{l}\text { Negotiates purchase of } \\
\text { machines and equipment }\end{array}$ & 8 & 6 & 9 & 8 & 8 & 5 & 5 & 5 & 5 \\
\hline $\begin{array}{l}\text { Decides when to sell crops or } \\
\text { livestock }\end{array}$ & 4 & 4 & 5 & 3 & 5 & 6 & 8 & 9 & 6 \\
\hline $\begin{array}{l}\text { Negotiates sales of crops or } \\
\text { livestock }\end{array}$ & 3 & 3 & 3 & 3 & 4 & 3 & 6 & 6 & 7 \\
\hline $\begin{array}{l}\text { Makes annual crop or livestock } \\
\text { plans }\end{array}$ & 7 & 8 & 4 & 7 & 9 & 10 & 11 & 8 & 7 \\
\hline Decides level of inputs used & 13 & 11 & 6 & 6 & 3 & & 9 & 10 & 8 \\
\hline Plans day-to-day work & 9 & 12 & 11 & 10 & 12 & 9 & 9 & 7 & 9 \\
\hline $\begin{array}{l}\text { Decides timing of operations or } \\
\text { activities }\end{array}$ & 10 & 9 & 7 & 11 & 10 & 8 & 7 & 7 & 10 \\
\hline $\begin{array}{l}\text { Decides type and make of } \\
\text { machines and equipment }\end{array}$ & 11 & 10 & 12 & 13 & 10 & 12 & 10 & 9 & 11 \\
\hline $\begin{array}{l}\text { Decides work method or } \\
\text { way jobs are done }\end{array}$ & 12 & 13 & 13 & 9 & 13 & 11 & 12 & 12 & 12 \\
\hline
\end{tabular}

Note: The numbers represent the rank order of decisionmaking authority retained by the older generation. 1 represents the activity most identified as retained solely by the older generation.

Note: One number may appear more than once for the same state or county. This is due to the fact that some activities and decisions had the same percentages attributed to them.

*Pennsylvania, New Jersey, and North Carolina surveys differed from those represented by the data in table 2 above. Therefore, not all activities and decisions have a rank score for Pennsylvania and New Jersey.

\section{The Succession Ladder}

The delegation of decisions and tasks can be referred to as the succession ladder, ${ }^{3}$ or a ladder of

\footnotetext{
${ }^{3}$ The concept of the succession ladder is well established and was first identified empirically by Commins and Kelleher (1973) in Ireland. Subsequent work, for example in New Zealand (Keating and Little, 1991) and in the UK (Hastings, 1984; Errington and Tranter, 1991), provides further empirical support for "the existence of a ladder of responsibility which successors climb en route to the acquisition of full managerial control" (Gasson and Errington, 1993, p. 213). Hastings (1984) made a major contribution to understanding the different decision domains (e.g., technical, strategic) and the order in which a successor passes though each domain. One of the contributions of FARMTRANSFERS has been to demonstrate the existence of the succession ladder and the broadly similar order of individual "rungs" on the ladder in
}

responsibility the successor will climb (Errington, 1998). In this model, the first type of decisions delegated to the successor are technical decisions, those involving the type and level of production inputs, such as feed or fertilizers, along with the tactical decisions concerned with the day-to-day planning of the farm operation. The next decisions delegated are the strategic planning decisions, such as the mix and type of enterprises. Successors will then make decisions such as when to hire more employees, and the recruitment, selection, and supervision of employees. Further up the ladder of

many different international contexts (e.g., Uchiyama, et al., 2008). 
responsibility, successors are then responsible for financial decisions, such as negotiating sales of crops or livestock, and identifying sources of and negotiating loans and financing. Finally, successors are responsible for deciding when to pay bills. This is most likely be one of the last areas of responsibility delegated to the successor (Errington, 1998). Such decisions, technical, tactical, strategic, and financial, are representative of rungs on the succession ladder.

Data from the international FARMTRANSFERS project found that France experiences a faster succession process than England, with Canada falling in the middle of the spectrum. Iowa has been found to have the slowest succession rate (Barclay, et al., 2005). Uchiyama, et al. (2008) found a relationship between the age of the successor and the amount of delegation. Specifically, as successors grow older, more tasks and decisions are delegated. However, while delegation of managerial authority increases evenly in Canada and Iowa, in England and Virginia the increase in delegation drops off after the age of 40 (Uchiyama, et al., 2008). An Australian study found that Australian farmers are more likely to delegate greater amount of managerial responsibility than farmers in Iowa and England, and a lesser amount than farmers in Canada and France (Barclay, 2005). See Uchiyama, et al. (2008) for further analysis of the association between delegation and age of successor and principal farmer.

\section{The Succession Process}

Previous studies have discussed the different routes that successors may take before taking over the farm operation (Uchiyama, et al., 2008). The two principal routes identified are: (1) the direct route, where successors go directly into farming after they leave school, and (2) the diversion route, where successors are employed in an off-farm job after leaving school and then return to the home farm operation at a later date. This is sometimes referred to as a professional detour (Gasson and Errington, 1993; Uchiyama, et al., 2008).

The succession route followed is likely to be influenced by a number of factors, including the availability of alternative employment and cultural norms regarding the value of nonfarm work. Uchiyama and colleagues found that farm size is a predictor of succession route. Generally, farms that are larger provide more opportunity for the older and younger generations to work side by side. Those successors who are on the direct route to succession are more likely than successors on the diversion route to develop intangible assets such as managerial skills (Uchiyama et al., 2008). In addition, successors who are from smaller farming operations are more likely to be employed off the farm, except for those successors in England and Virginia.

FARMTRANSFERS project results can be used to explore patterns of succession based on the successor's current farm activity and the degree of decisionmaking authority that he or she has (Errington and Lobley, 2002). Errington and Lobley identified two distinctions in the pattern of succession: the responsibility exercised by the successor in making decisions on the farm, and the extent to which he or she is able to run an autonomous enterprise (Errington and Lobley, 2002). They used this to empirically identify different types of successors previously conceived of as conceptual "ideal types" by Gasson and Errington (1993).

The first category of successor is the Farmer's Boy, in which the successor has little or no responsibility for decisionmaking and provides mainly manual labor on the farm. This category is common in England, as demonstrated by the FARMTRANSFERS Surveys (e.g., Uchiyama, et al., 2008; Errington and Lobley, 2002). The second category is the Separate Enterprise, where the home farm operation is large enough to support a separate enterprise run by the successor. This category allows the successor to develop managerial skills and also allows for some financial autonomy (Gasson and Errington, 1993). The third category of successor is the Stand-By Holding, in which the successor is set up on a separate farm in order to develop his or her farming skills. Although the successor might share machinery or labor at some point, he or she still remains independent of 
the farmer. The last category of successor is Partnership. In a partnership, the farmer works with the successor and shares responsibility for decisionmaking. A formal partnership agreement may even be executed (Gasson and Errington, 1993).

Successors in Canada and the U.S. are more likely to take a professional detour route - a nonfarm job right out of school before returning to the farm operation. Few U.S. successors run a stand by farm. English successors are more likely to be in the farmer's boy category for a longer period of time compared with their counterparts in the U.S. and Canada. English and Canadian successors are more likely to run a separate enterprise to develop farming skills necessary for farm operation (Lobley and Errington, 1998).

\section{Retirement}

Succession and retirement are intimately interlinked. The incorporation of a successor into the business can offer the principal farmer the opportunity to semiretire, while in equal measure, the unwillingness of a senior farmer to step back can hinder the succession process. Evidence from FARMTRANSFERS surveys indicates that farmers in Iowa, Virginia, and North Carolina are more likely to remain employed on the farm operation, are less likely to semiretire from farming, and indicate that they will never retire. Farmers in Australia, England, Ontario, and Quebec are more likely to experience semiretirement or full retirement from farming (see figure 3). The identification of a successor is associated with a path of semiretirement from farming, in that those farmers who have identified a successor are more likely to experience some form of semiretirement. This trend occurs regardless of nationality. The presence of a successor might make semiretirement a realistic option for farmers who may otherwise face a choice of continuing to work full-time or completely retiring. Interestingly, farmers are less likely to choose a form of semiretirement if their successors are employed off the farm (Uchiyama, et al., 2008).
Not only do retirement plans vary significantly across the FARMTRANSFERS replications being considered here, but so does the average age of planned retirement. As figure 4 indicates, farmers in the United States tend to plan to retire at an older age than their counterparts in Canada, France, and England. Australian farmers, however, indicated in a 2004 survey that the average age of retirement is 65, similar to U.S. farmers (Barclay, et al., 2005).

The ability to finance retirement is likely to be one of a number of factors influencing retirement plans. Figure 5 presents comparative data on anticipated sources of retirement income and illustrates some significant differences between FARMTRANSFERS replications. The two Canadian replications (Ontario and Quebec) are notable for the significance of the sale of farm land or other farm assets in order to fund retirement. Farmers in France, on the other hand, gain the largest proportion (48 percent) of their retirement income from social security payments, while farmers in England tend to gain a significant proportion of their retirement income from private pension provision.

The decision to retire and step back from a career that is often characterized as a "way of life," and one in which much of an individual's and family's social, cultural, and economic history and identity is conjoined, is not always an easy decision to reach. Advice on retirement planning can therefore be very important. Table 3 shows the comparison between countries of farmer respondents ages 50 59 and their discussions of retirement. Canadian and Iowan farmers are more likely to discuss their retirement plans with family members; however, farmers in England are less likely to do so. Previous studies have shown that retirement discussions with family members often increase after the identification of a successor (Uchiyama, et al., 2008), although this varies by location. 
Figure 3. Farmers retirement plans: some international comparisons

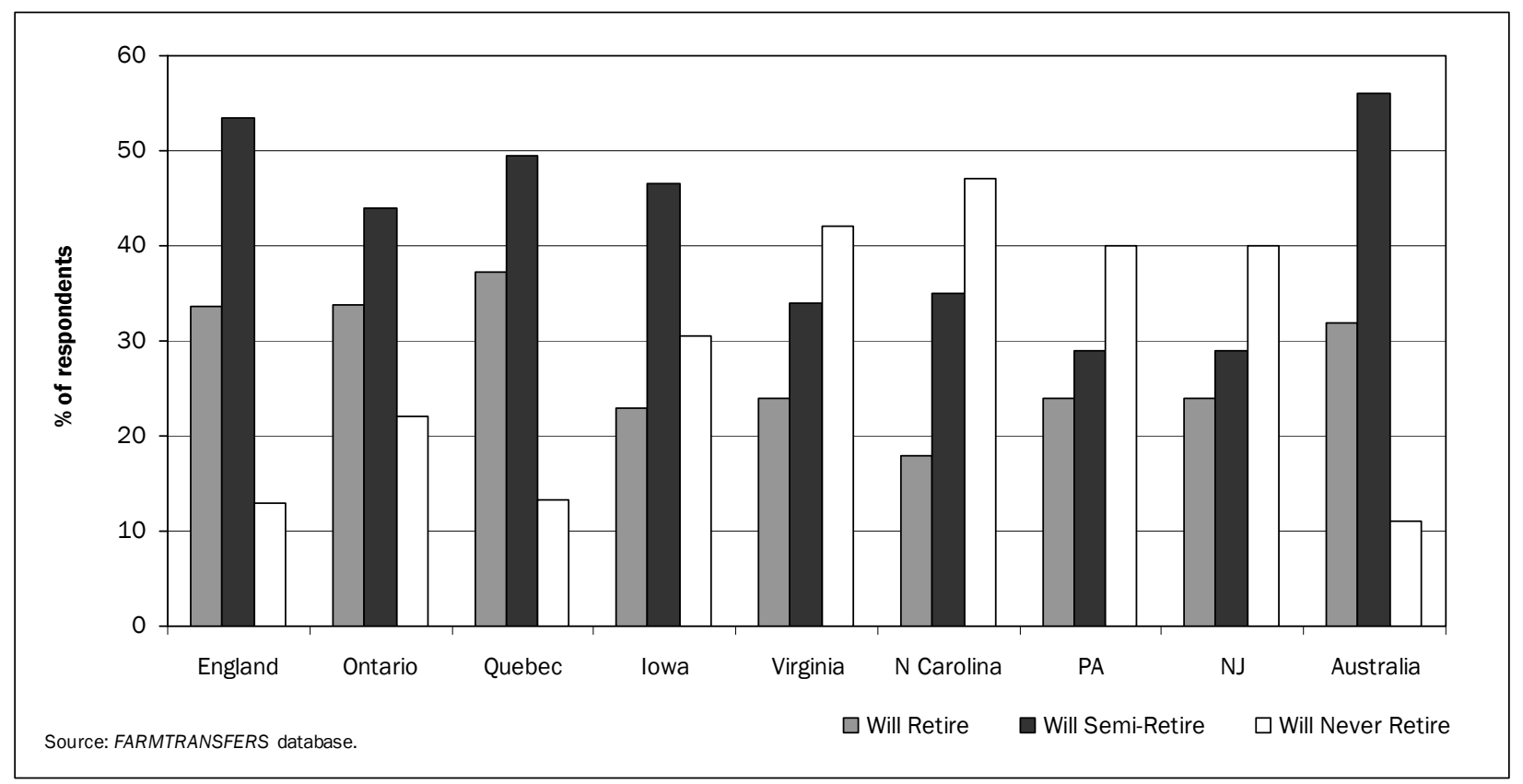

Figure 4. Mean anticipated retirement age

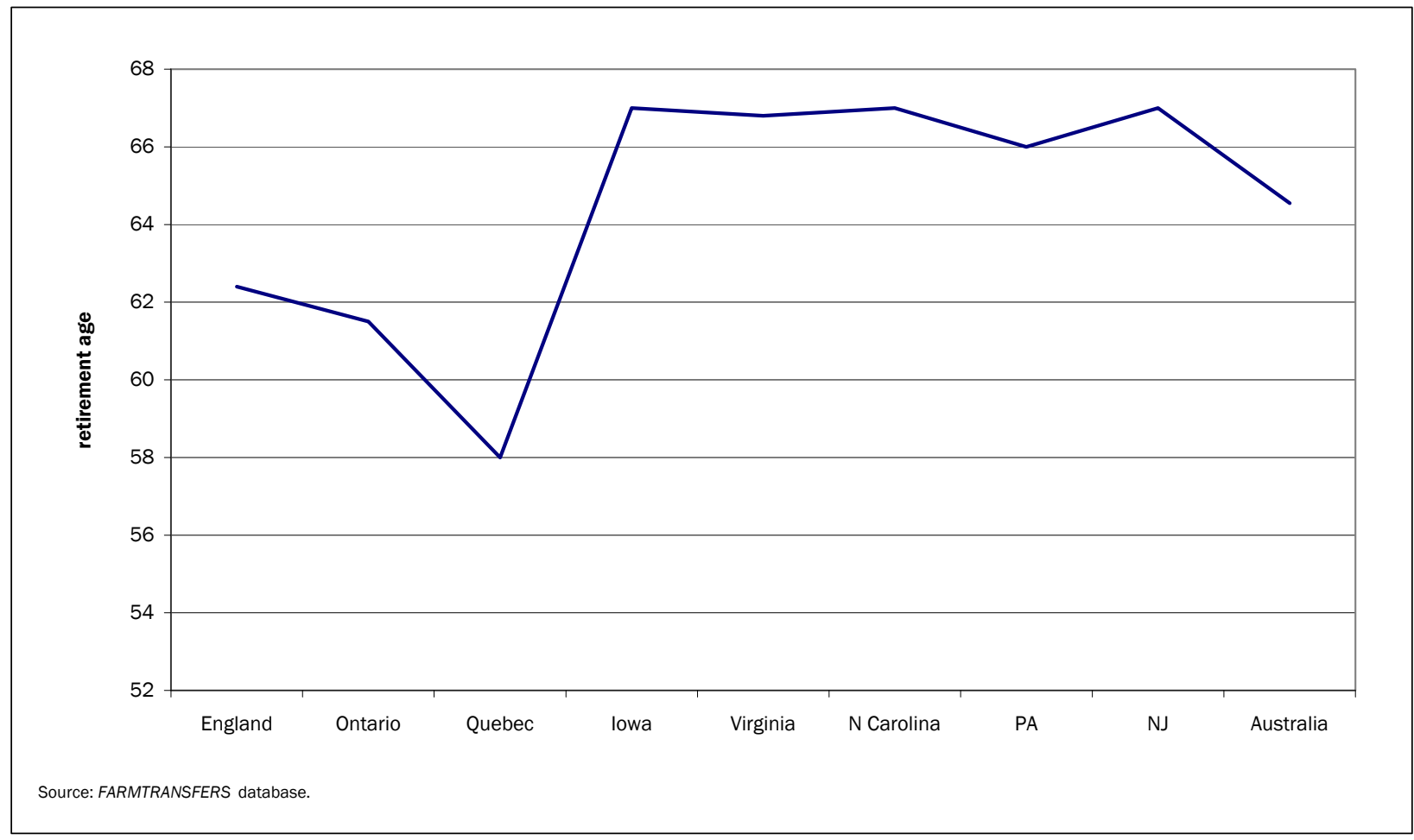


Figure 5. Anticipated sources of retirement income: Some international comparisons

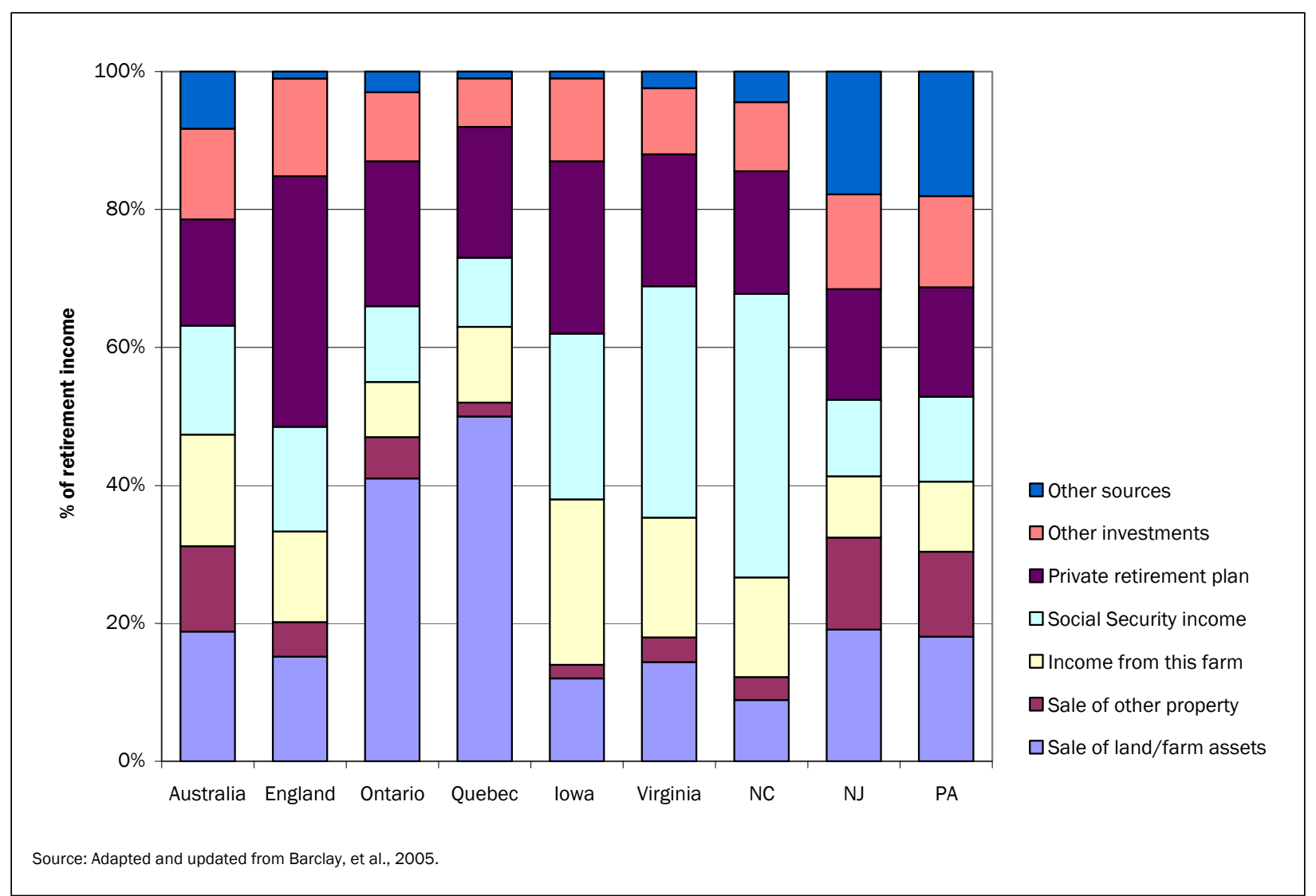

Table 3. International retirement discussions

(\% of respondents)

\begin{tabular}{lrrrrrrrrr}
\hline Type of discussant & England & Ontario & Quebec & IA & VA & NC & PA & NJ & Australia \\
\hline Family & 28 & 63 & 63 & 46 & 66 & 25 & 31 & 31 & 59 \\
Lawyer & 14 & 7 & 10 & 17 & 10 & 0 & 9 & 9 & 9 \\
Banker & 7 & 10 & 7 & 8 & 1 & 0 & 3 & 3 & 10 \\
Accountant & 39 & 38 & 33 & 19 & 11 & 0 & 13 & 13 & 40 \\
Farm consultant & 0 & 5 & 11 & 3 & 2 & 0 & 2 & 2 & 8 \\
Other farm advisor & 4 & 7 & 6 & 0 & 0 & 7 & 4 & 4 & 9 \\
Other & 7 & 10 & 6 & 3 & 1 & 1 & 2 & 2 & 5 \\
No one & 44 & 28 & 28 & 47 & 30 & 67 & 21 & 21 & 9 \\
\hline
\end{tabular}

Total sums to more than $100 \%$, as some respondents indicated more than one category.

Source: Barclay, et al., 2005; FARMTRANSFERS database. 


\section{Discussion}

\section{Policy Implications}

This section begins with a brief review of contemporary challenges for agriculture. This provides the context in which to reflect on the place of family farms in addressing these challenges and the importance of timely and effective transfers of property and/or businesses in the farming industry.

\section{Challenges for Agriculture at Global, Regional, and Local Levels}

Arguably, the last two decades have presented the most significant challenges for agriculture in the post-war period. The focus of attention centers on the capacity of resources and practices in global agriculture to meet increasing demands for food, from rising populations and changing diets, along with a raft of other goods (i.e., bioenergy and industrial crops) and services (i.e., conservation and recreation) in the context of volatile commodity prices, diminishing nonrenewable resources, and climate change. Concurrent with such challenges, there is increasing evidence of continued degradation of the soil arising from continued unsustainable, intensive agricultural practices in areas of the world, including Australia, the U.S. and the UK. A decade ago, the Policy Commission on the Future of Food and Farming in the UK (Policy Commission, 2002) warned of the unsustainability of commercial farming practices. More recently, the UK Department of Environment, Food and Rural Affairs (DEFRA) has launched the country's first Food Security Assessment (DEFRA, 2009a), followed in close succession with the publication of DEFRA's vision 2030 - Safeguarding Our Soils: A Strategy for England (DEFRA, 2009b).

Similarly, interest in beginning and farm succession planning has increased in the United States. The 2008 farm bill, part of the Food, Conservation, and Energy Act of 2008, established the Beginning Farmer/Rancher Development Program. The goal of the program is to enhance the food security of the United States by providing beginning farmers and ranchers and their families with the necessary knowledge and skills to make decisions concerning the future sustainable farming of their properties. The challenges to farming will vary geographically in nature and degree. In Eastern Europe, they will differ from those of Eastern Australia or the uplands of England. In a recent review of the challenges to rural land management, Hodge (2009, p. 652) states that "farm businesses need to develop their resilience in the face of greater exposure to the volatilities of world markets and reduced level of support under agricultural policy," as well as the uncertainties of climate change. Such "resilience" is the preserve of many family farms, and arguments for this are familiar. Jones (1996, p. 197) refers to the importance of the "intimate coaxing style of management" of family farms and advantages as "a long term institution protecting not only its economic base, but also its own place and surrounding." Continuity of management, through close relationships between family members, and the "sharing" of capital assets and the detailed knowledge of the farm resource, all contribute to the strength of family farms. The successors of the future will have to be highly motivated, skilled in technical and business matters, and capable of pre-empting change and planning appropriate responses. Without this, the risk is that the cornerstone of agricultural business in these countries will fail to meet national and global expectations.

\section{Impacts of Effective and Less Effective Succession} As an entry route to agriculture, succession can have a significant impact on the contribution of farming in terms of economic, environmental, and social benefits. It has been argued that "succession and the failure of succession can have a powerful influence on the development trajectory of a farm" Lobley (2010, p. 1). Effectiveness can perhaps be measured first in terms of the presence of a successor to the business, and, second, in the timeliness and "smoothness" of transfer to that successor of the business. As previously mentioned, the business and the industry as a whole can derive benefit from the so-called "succession effect," which arises from the early identification of a successor and leads to determined development of the business to a state where two generations can be supported. Similarly, previous discussion has 
also centered on the "successor effect," a renewed enthusiasm for the business, as the parties begin to share managerial responsibilities. In challenging times, these two "effects" are clearly in the interests of efficient farming for the business and the country, providing perhaps the best model for succession. Clearly, there are policy implications in terms of providing favorable circumstances for the achievement of such effects and the benefits to be gained from them.

Where a successor has been identified, the sequential transfer of the "reins of the business" may be slower than optimal. This has been identified as the case in the latest survey for England (1997), as well as in Germany (2003), Austria (2003) and North Carolina (2005), where the "farmer's boy" category of successor is dominant. In policy terms, a high proportion of "farmer's boy" successors suggests potential lack of wider farming knowledge, business and managerial skills, and the motivation required to drive the business forward in such uncertain times. Multiplied up, this may lead to farm businesses less well placed to adapt to and succeed in responding to the challenges of the future. Closely related to this is the barrier of low retirement rates in farming, identified in research conducted for DEFRA on Entry to and Exit from Farming in the UK (ADAS, 2004) and confirmed as an international feature of farm businesses, earlier in this paper. For many, such a strong reluctance to retire is due to the decision to farm as a long-term lifestyle choice. However, other barriers may also exist, including inadequacy of pension provision and the lack of affordable housing for the retiree or the successor.

Of course, there may be other causes for a lack of a successor and implications if that occurs. In some cases farmers may just not have had children. In others, the farmer's children may become disinterested in the family business to the extent of losing any intention to succeed. This may be a product of the "late" recognition of the need for and discussion with potential successors. FARMTRANSFERS survey findings indicate successor age to range between 40 and 60 years old, with a wider range of ages at which the principal farmer identifies the successor. Without a clear successor, the business, the land and the building complement stand to be transferred to an operator new to the farmland, whether retained as a whole unit or separate lots. A time lag thus begins between takeover of this farm resource and its effective management, during which time obstacles may arise, financial and otherwise, to its continuing use as farmland. Where environmental objectives are important, such as for nature conservation to protect particular habitats, this lag time could be particularly important and may result in unnoticed decline.

Finally, in terms of implications for wider society, commentators have expressed concern over the apparent aging of the farming community. Although not commonly the focus of succession research, investigations are required into the impact of earlier succession on the relationships between farm and community and the potential for younger farmers and their families to contribute to rural development.

\section{Conclusions}

There is much to consider here for researchers, policymakers, farm business advisers and farm business principals and prospective successors. In terms of research there is a continuing need to develop a clearer understanding of the process of intergenerational transfer in countries across the globe. Obvious research gaps exist in space (geographical coverage) as well as in time (up-todate evidence). Such deficiencies preclude the spread of good practice. On the question of retirement, qualitative research is needed to investigate the key influences over decisions in this regard. What scope is there to encourage planned retirement more broadly in the farming industry?

In terms of policy, consideration focuses on three areas: first, measures to assist with increasing the likelihood of succession, that is, the presence of a successor motivated to take over the oftmentioned "reins of the business"; second, measures to encourage early identification of, and discussions with, the successor(s), to include the 
development of plans for "handing over the reins of the business"; and, third, measures designed to reduce the apparent barriers to retirement. As previously mentioned, replications within the FARMTRANSFERS project across a range of countries and states has provided evidence highlighting, perhaps not surprisingly, variations in some aspects of retirement and succession issues. The relevance of the three types of measures mentioned above therefore also will vary.

The attraction of agriculture as a career is crucial to continued motivation of potential successors to take on the family farm. Student applications to agricultural colleges and universities have decreased dramatically in the last three decades in the UK, resulting in the reduction of postschool educational provision in agriculture as departments close across the country. To reverse this situation, a redoubling of effort is required to convey the message that sustainable agriculture has a key role to play in a future of global population growth (food security), pressures to reduce carbon emissions (waste management and renewable energy opportunities), and climate change. Rewarding career opportunities will continue to develop in these areas. Such messages need to be conveyed convincingly by government, educational institutions, and farming organizations. Resources should also be made available to deal with future increases in demand for training and education in what must be seen as a renaissance in the farming industry. The main objective here is to increase the potential for a heightened "successor" effect in farm businesses - the return of enthusiastic and well trained young farmers to their family businesses.

As for the second focus of policy action, the FARMTRANSFERS project has uncovered variation in the age at which the principal farmer identifies a successor. In some countries, such as Australia, this is achieved earlier than others. Late commitment to a successor can result in unprepared semiretirees or full retirees, unprepared successors, and unprepared businesses. Mere identification of a successor is not enough; this project has also seen variation in the rate and approach to handing over the reins. Retirement offers opportunities for not only successors but also for retirees wishing to reduce their involvement physically, managerially, and financially over a period of time. For the industry, a mutually agreed upon retirement program can benefit all parties and the industry generally. In many other businesses, full retirement is the norm. In family farms, the knowledge and skills of the retiree are retained as a valuable asset to the business. A planned retirement program is therefore beneficial. Where appropriate, consideration should be given to funding for or direct provision of advice and training for farm business succession planning, through seminars, workshops, consultations, and publications, either directly with farming principals and prospective successors or via farm advisers. The main objectives here would to increase the "succession effect" by encouraging early identification and discussion between parties and to reduce the likelihood of the "farmer's boy" model of successors, identified as typical in England.

Finally, this paper has confirmed the international significance of barriers to retirement in the industry. Again, these vary geographically and may include a combination of internally imposed issues and/or externally imposed constraints. Regarding the former, lack of motivation to retire is the product of a range of actual or perceived issues which might include the importance of farming as "a way of life," including home and stock, the perception of a shortage of appropriate skills for other opportunities in retirement, and the reluctance to consider training to acquire new skills. In addition, lack of early planning may lead to inadequate pension provisions, causing the need for continued dependence on the farm business. Policy directions involving support for advice and "training for retirement," mentioned above, would be appropriate here.

In terms of externally imposed constraints, a lack of affordable housing in the locality may be a major problem. Retirees may prefer to remain in the vicinity of the family farm and more flexible approaches to planning decisions may need to be 
considered. Financial constraints for the successor who is expected to take on some or all of the business assets could also delay decisionmaking. Improvement in the availability of loans on manageable terms, along with the review of grant provision to encourage successors to take over and develop their family businesses, could be appropriate, depending on prevailing "local" (state or national) circumstances. The international prominence of succession as the means of farm transfer should, alone, suggest the need for greater understanding and effort, to ensure that farm businesses have the best chance to remain (or become) strong and competitive, with the complement of assets to face the challenges of the future.

\section{Acknowledgements}

We are grateful to all the farmers who have taken the time to complete a FARMTRANSFERS questionnaire and to our research partners. We are particularly grateful to the late Professor Andrew Errington for instigating FARMTRANSFERS and inspiring this work. A special thank you to Anne E. Hensley, Beginning Farmer Center, Iowa State University, for her invaluable assistance in analyzing the data and aid in drafting this article.

\section{References}

ADAS Consulting Ltd., University of Plymouth, Queen's University Belfast and the Scottish Agricultural College. (2004). Entry to and exit from farming in the UK (Report to the Department of Environment, Food and Rural Affairs (DEFRA)). ADAS, Wolverhampton, UK.

Baker, J. Duffy, M. and Lamberti, A. (2001). Farm Succession in Iowa. Beginning Farmer Center, Iowa State University

Barclay, E., Foskey, R. \& Reeve, I. (2005). Farm succession and inheritance: Comparing Australian and international research. The Institute for Rural Futures, University of New England, Armidale, NSW, Australia.

Boehlje, M. D. \& Eidman, V. R. (1984). Farm management. New York, NY: John Wiley.

Burton, R., Mansfield, L., Schwarz, G., Brown, K. \& Convery, I. (2005). Social capital in bill farming. The Macaulay Land Use Research Institute, Aberdeen, UK.

Burton, R. \& Walford, N. (2005). Multiple succession and land division on family farms in the South East of England: A counterbalance to agricultural concentration? Journal of Rural Studies, 21, 335-347.
Calus, M., Huylenbroeck, G. \& Lierde, D. (2008). The relationship between farm succession and farm assets on Belgian farms. Sociologia Ruralis, 48, 38-56.

Clay, H. (2006). Virginia's oldest institutions: From Shirley Plantation to Burke and Herbert Bank. Retrieved from www.fairfaxcounty.gov/library/ niceandcurious/oldestinstitutions.htm.

Commins, P. and Kelleher, C. (1973). Farm inheritance and succession. Macra Na Feirme, Irish Farm Centre, Dublin, Ireland.

Department of Environment, Food and Rural Affairs (DEFRA). (2009a). UK food security assessment: Our approach. DEFRA, London, UK. Retrieved at www.defra.gov.uk/foodfarm/food/pdf/foodassess-approach-0908.pdf.

Department of Environment, Food and Rural Affairs (DEFRA). (2009b). Safeguarding our soils: A strategy for England. DEFRA, London, UK. Retrieved at www.defra.gov.uk/environment/quality/land/soil/ documents/soil-strategy.pdf.

Errington, A.J. (1998). The intergenerational transfer of managerial control in the farm-family business: A comparative study in England, France and Canada. Journal of Agricultural Education and Extension, 5, 123-36.

Errington, A. J. \& Lobley, M. (2002, April). Handing over the reins: A comparative study of intergenerational farm transfers in England, France, Canada and the USA. Paper presented at the meeting of the Agricultural Economics Society, Aberystwyth, UK.

Errington, A. J. \& Tranter, R. B. (1991). Getting out of Farming? Part two: The farmers. (Reading University Farm Management Unit, Study No. 27).

Gasson, R. \& Errington, A. J. (1993). The farm family business. Wallingford, UK: CAB International.

Harl, N. E. (1972). The family corporation. In Ball, A. G. \& Heady, E. O. (Eds.), Size, structure, and future of farms. Ames, IA: Iowa State University Press.

Hastings, M. (1984). Succession on farms. (Unpublished MSc Thesis). Cranfield, UK: Cranfield Institute of Technology.

Hodge, I. (2009). Scenarios for rural land management: Exploring alternative futures. Journal of Farm Management, 13, 633-654.

Hoppe, R. and Banker, D. (2006). Structure and Finances of US Farms, Economic Information Bulletin 12, May 2006, Economic Research Service, United States Department of Agriculture.

Jones, C. (1996). Family survival and family values. In Carruther, S.P. \& Miller, F.A. (Eds.) Crisis on the family farm: Ethics or economics? (CAS Paper 28, Proceedings of a conference organized by the Centre for Agricultural Strategy, March 1993). Reading, UK: Centre for Agricultural Strategy. 
Keating, N. \& Little, H. (1991). Generations in farm families: Transfer of the family farm in New Zealand. (Research Report No. 208). Lincoln, UK: Agribusiness and Economics Research Unit, Lincoln University.

Korsching, P., Lasley, P. \& Gruber, T. (2007). Iowa Rural Life Poll Survey Report on Farmer Entrepreneurship. Iowa State University.

Laband, D. \& Lentz, B. (1983). Occupational inheritance in agriculture. American Journal of Agricultural Economics, 65, 311-14.

Lobley, M. (2010, January). Succession in the family farm business. Paper presented at the Oxford Farming Conference, Oxford, UK.

Lobley, M., Errington, A., McGeorge, A., Millard, N., \& Potter, C. (2002). Implications of changes in the structure of agricultural businesses. University of Plymouth, Seale-Hayne Campus, UK: Department of Land Use and Rural Management.

Lobley, M. \& Potter, C. (2004). Agricultural change and restructuring: recent evidence from a survey of agricultural households in England, Journal of Rural Studies, 20, 499-510.

Mishra, A. \& El-Osta, H. (2008). Effect of agricultural policy on succession decisions of farm households. Review of Economics of the Household, 6, 285-307.
National Park Service (2007). The Last Homesteader. Retrieved from www.nps.gov/home/ historyculture/lasthomesteader.htm.

Policy Commission on the Future of Food and Farming. (2002). Farming and food: a sustainable future. Cabinet Office, London, UK. Retrieved from archive.cabinetoffice.gov.uk/farming/pdf/PC $\% 20$ Report2.pdf.

Potter, C. \& Lobley, M. (1992) Ageing and succession on family farms. Sociologia Ruralis, 32, 317-334.

Potter, C. \& Lobley, M. (1996) Unbroken threads? Succession and its effects on family farms in Britain. Sociologia Ruralis, 36, 286-306.

Rosenblatt, P.C. \& Anderson, R.M. (1981). Interaction in farm families: Tension and stress. In Coward, R.T. \& Smith, W.M. (Eds.), The family in rural society (pp. 147-166). Boulder, CO: Westview Press.

Symes, D. (1973). Stability and change among farming communities in southwest Ireland, Acta Ethnographica Academiae Scientiarum Hungaricae, 11, 89-105.

Symes, D. (1990). Bridging the generations: Succession and inheritance in a changing world. Sociologia Ruralis, 30, 280-291.

Uchiyama T., Lobley M., Errington A., \& Yanagimura S. (2008). Dimensions of intergenerational farm business transfers in Canada, England, the USA and Japan, Japanese Journal of Rural Economics, 10, 33-48. 